\title{
Hubungan Dukungan Suami dengan Pemberian ASI Eksklusif : Literature Review
}

\author{
Sapitri Wulandari ${ }^{*}$, Emi Nurlaela ${ }^{2}$ \\ 1,2 Program Studi Sarjana Keperawatan, Universitas Muhammadiayah Pekajangan Pekalongan, \\ Indonesia \\ *email:sapitri.wulandari0601@gmail.com
}

\begin{abstract}
Global study "The Lancer Breastfeeding Series" 2016 explains that infant mortality due to infection reaches $88 \%$ in infants aged less than three months, while $82 \%$ of children get sick because they do not receive exclusive breastfeeding. Exclusive breastfeeding can reduce infant mortality due to infection. Several factors that affect exclusive breastfeeding are the mother, the infant, and support factors. One of the sources of support that can affect exclusive breastfeeding is the husband's support. This study aimed to determine the relationship between husband's support and exclusive breastfeeding through a literature review. This study uses a literature review method. The articles used are sourced from online databases with electronic searches on Google Scholar and Garuda Portal published in 20112021. The critical assessment instrument used is the STROBE instrument. Based on the 6 articles used in the litarture review, the results showed that in 3 articles namely research from Fitriani (2020), Rolita (2020), and Aries (2019), there was a correlation between the husband's support and exclusive breastfeeding. Meanwhile, in the other three articles namely research fromIndriyani (2019), Novira (2017), and Rahayu (2018), there was no correlation between the husband's support and exclusive breastfeeding. Husband's support is related to exclusive breastfeeding, so that the management of nursing care for breastfeeding mothers should involve the husband.
\end{abstract}

Keywords: Exclusives breastfeeding; husband's support

\begin{abstract}
Abstrak
Kajian Global "The Lancer Breastefeeding Series" 2016 menjelaskan bahwa kematian bayi karena infeksi mencapai angka $88 \%$ pada bayi berusia kurang dari 3 bulan, sedangkan $82 \%$ anak sakit karena tidak menerima ASI Eksklusif. Pemberian ASI Eksklusif dapat menurunkan angka kematian pada bayi akibat infeksi. Beberapa faktor yang berpengaruh terhadap pemberian ASI Eksklusif diantaranya faktor ibu, bayi, dan dukungan. Sumber dukungan yang dapat mempengaruhi pemberian ASI Eksklusif salah satunya dukungan suami. Penelitian ini bertujuan untuk mengetahui hubungan dukungan suami dengan pemberian ASI Eksklusif melalui literature review. Penelitian ini menggunakan metodeliterature rev iew. Artikel yang digunakan bersumber dari data base online dengan penelusuran elektronik pada Google Scholar dan Portal Garuda yang terbit pada tahun 2011-2021. Instrumen telaah kritis yang digunakan yaitu instrumen STROBE. Berdasarkan 6 artikel yang digunakan dalam literature review didapatkan hasil penelitian menyebutkan bahwa 3 artikel yaitu penelitian dari Fitriani (2020), Rolita (2020), dan Aries (2019) terdapat hubungan antara dukungan suami dengan pemberian ASI Eksklusif dan 3 artikel yaitu penelitian dari Indriyani (2019), Novira (2017), dan Rahayu (2018) tidak terdapat hubungan antara dukungan suami dengan pemberian ASI Eksklusif. Dukungan suami berhubungan dengan pemberian ASI eksklusif, sehingga dalam kelolaan asuhan keperawatan pada ibu menyusui seharusnya melibatkan suami.
\end{abstract}

Kata Kunci : Exclusives breastfeeding; husband's support; pemberian ASI Eksklusif; dukungan suami 


\section{Prosiding Seminar Nasional Kesehatan $\mid 2021$ Lembaga Penelitian dan Pengabdian Masyarakat Universitas Muhammadiyah Pekajangan Pekalongan}

\section{Pendahuluan}

Pemeliharaan kesehatan anak merupakan upaya yang ditujukan untuk mempersiapkan generasi sehat, cerdas dan berkualitas pada masa mendatang yang dapat diwujudkan melalui pemberian Air Susu Ibu (ASI) secara Eksklusif [1]. Berdasarkan aturan yang telah ditetapkan oleh pemerintah nomor 33 tahun 2012 tentang pemberian Air Susu Ibu Eksklusif adalah ASI yang diberikan kepada bayi sejak dilahirkan selama 6 bulan, tanpa menambahkan atau mengganti dengan makanan atau minuman lain kecuali mineral, obat, dan vitamin [2]. Menurut Mufdilah, 2019 World Health Organization (WHO) juga merekomendasikan pemberian ASI Eksklusif selama 6 bulan pertama secara terus menyusui sampai usia dua tahun, dan dilanjutkan setelah enam bulan bersamaan dengan pemberian MPASI (makanan pendamping ASI) [3].

Air Susu Ibu (ASI) merupakan makanan terbaik bagi bayi, khususnya bayi usia 0-6 bulan, yang fungsinya tidak dapat digantikan oleh makanan dan minuman apapun. Pemberian ASI merupakan pemenuhan hak bagi setiap ibu dan anak[4]. Pemberian ASI Eksklusif dapat menurunkan angka kematian pada bayi akibat infeksi. Kajian Global "The Lancer Breastefeeding Series" 2016 menjelaskan bahwa kematian bayi karena infeksi mencapai angka $88 \%$ pada bayi berusia kurang dari 3 bulan, sedangkan $82 \%$ anak sakit karena tidak menerima ASI Eksklusif [5]. Angka kematian bayi pada tahun 2019 di Indonesia mencapai 24 per 1.000 kelahiran hidup [2].8,2 per 1.000 kelahiran hidup di Jawa Tengah serta 12 per 1000 kelahiran hidup di kota Pekalongan dan 8,7 per 1.000 kelahiran hidup di kabupaten Pekalongan. Angka kematian bayi sebagian besar diakibatkan karena infeksi [6].

United Nations Children Fund (UNICEF) menyebutkan pada tahun 2018 prevalensi pemberian ASI Eksklusif di dunia sebesar 42 \%[7]. Secara nasional, prevalensi bayi mendapat ASI Eksklusif tahun 2019 yaitu sebesar 67,74\%. Angka tersebut sudah melampaui target Renstra tahun 2019 yaitu 50\%. Prevalensi pemberian ASI Eksklusif di Jawa Tengah pada tahun 2019 sebesar 66,0 \%, jumlah ini meningkat dibandingkan presentase tahun lalu (2018) sebesar 65,5\%. Sedangkan pemberian ASI Eksklusif di Kota maupun Kabupaten Pekalongan pada tahun 2019 masing-masing sebesar 57,2 \% [6].

Beberapa faktor yang berpengaruh terhadap pemberian ASI Eksklusif, diantaranya faktor ibu, bayi, dan dukungan. Sumber dukungan yang dapat mempengaruhi pemberian ASI Eksklusif diantaranya yaitu dukungan suami, orang tua, dan tim kesehatan [8]. Kelancaran produksi ASI sangat dipengaruhi oleh dukungan suami. Hal tersebut dapat memberikan manfaat berupa produksi ASI yang lancar. Suami berperan penting breastfeeding father, yaitu membantu dalam keberhasilan menyusui. Sebagai Breastfeeding father adalah peran suami dengan cara memberi dukungan kepada ibu agar bisa menyusui dengan nyaman sehingga ASI yang dihasilkan maksimal [9]. Hal ini sejalan dengan penelitian yang dilakukan oleh Astuti [10] menunjukan bahwa hasil analisis didapatkan nilai $\mathrm{OR}=9,866$ artinya ibu yang mempunyai peranan suami mempunyai peluang 9,68 kali untuk memberikan ASI Eksklusif. Studi tersebut menunjukan kemampuan suami dalam memberikan dukungan dalam pemberian ASI Eksklusif. 


\section{Prosiding Seminar Nasional Kesehatan Lembaga Penelitian dan Pengabdian Masyarakat Universitas Muhammadiyah Pekajangan Pekalongan}

Keberhasilan dan kesuksesan proses pemberian ASI Eksklusif ditentukan oleh peran suami sebagai breastfeeding father karena akan turut menentukan kelancaran refleks pengeluaran ASI yang sangat dipengaruhi oleh keadaan emosi atau perasaan ibu[11]. Fertaeni et al. [1] menjelaskan bahwa suami yang memiliki dukungan terhadap pemberian ASI Eksklusif akan memberikan dampak yang baik bagi ibu dalam pemberian ASI Eksklusif. Keberhasilan menyusui merupakan upaya bersama, membutuhkan informasi yang benar, dan dukungan kuat untuk menciptakan lingkungan yang memungkinkan ibu dapat menyusui secara optimal.

\section{Metode}

Penelitianini menggunakan metode literature review. Artikel yang digunakan bersumber dari database online dengan penelusuran elektronik pada Google Scholar dan Portal Garuda yang terbit pada tahun 2011-2021. Instrumen telaah kritis yang digunakan yaitu instrumen STROBE (Strengthening the Reporting of Observational Studies in Epidemiology) dalam Bahasa Indonesia berarti penguatan pelaporan studi desain observational pada epidemiologi yang digunakan sebagai dasar pelaporan literature review. Pencarian artikel menggunakan kata kunci Bahasa Indonesia "Dukungan suami", "pemberian ASI Eksklusif" untuk pencarian pada database Google Scholar didapatkan 3.930 artikel dan Portal Garuda 16. Sedangkan pada pencarian artikel Bahasa Inggris di google scholar menggunakan kata kunci "Husband's Support", "Exclusive Breastfeeding" didapatkan 11.700 artikel. Kemudian artikel diidentifikasi berdasarkan judul dan abstrak didapatkan 35 artikel untuk google scholar dan 5 artikel untuk portal garuda. Artikel yang sesuai dengan criteria inklusi dan eksklusi didapatkan 6 artikel. Kriteria inklusi pada penelitian ini adalah sebagai berikut : Artikel yang digunakan sesuai dengan kata kunci Bahasa Indonesia dan Bahasa Inggris. Tahun penerbitan jurnal dalam rentang waktu 10 tahun terakhir yaitu 2011-2021. Artikel yang digunakan sudah terindeks resmi dalam beberapa media penyedia jurnal. Artikel yang digunakan memiliki komponen naskah standar atau teks lengkap.

\section{Hasil dan Pembahasan Hasil}

\section{Hasil}

Tabel 1. Karakteristik Responden Berdasarkan Umur

\begin{tabular}{|c|c|c|c|c|c|c|c|c|c|c|c|}
\hline \multirow{3}{*}{ Penulis } & \multicolumn{2}{|l|}{ Artikel } & \multicolumn{9}{|c|}{ Usia } \\
\hline & \multirow[t]{2}{*}{ Tahun } & \multirow[t]{2}{*}{ Negara } & \multicolumn{2}{|c|}{$\begin{array}{c}<20 \\
\text { tahun }\end{array}$} & \multicolumn{2}{|c|}{$\begin{array}{l}20-35 \\
\text { tahun } \\
\end{array}$} & \multicolumn{2}{|c|}{$\begin{array}{c}<35 \\
\text { tahun }\end{array}$} & \multicolumn{2}{|c|}{$\begin{array}{c}>35 \\
\text { tahun }\end{array}$} & \multirow{2}{*}{$\begin{array}{l}\text { Jumla } \\
\text { hresp } \\
\text { onden }\end{array}$} \\
\hline & & & $\mathbf{F}$ & $\%$ & $\mathbf{F}$ & $\%$ & $\mathbf{F}$ & $\%$ & $\mathbf{F}$ & $\%$ & \\
\hline $\begin{array}{l}\text { Indriyani } \\
\text { dkk }\end{array}$ & 2019 & Indonesia & 1 & $\begin{array}{c}1,2 \\
0\end{array}$ & 65 & $\begin{array}{c}78, \\
1\end{array}$ & NM & NM & 17 & 20,4 & 83 \\
\hline $\begin{array}{l}\text { Novira K, } \\
\text { \&Triska N }\end{array}$ & 2017 & Indonesia & NM & NM & NM & NM & 60 & $\begin{array}{c}90, \\
9\end{array}$ & 6 & 9,0 & 66 \\
\hline $\begin{array}{l}\text { FitrianiNa } \\
\text { sution }\end{array}$ & 2020 & Indonesia & NM & NM & NM & NM & 83 & $\begin{array}{c}78, \\
30 \\
\end{array}$ & 23 & $\begin{array}{c}21,6 \\
9\end{array}$ & 106 \\
\hline $\begin{array}{l}\text { RolitaEfri } \\
\text { ani, } \\
\text { \&Dhesi A }\end{array}$ & 2020 & Indonesia & 12 & $\begin{array}{l}18, \\
75\end{array}$ & 39 & $\begin{array}{c}60, \\
9\end{array}$ & NM & NM & 13 & $\begin{array}{c}20,3 \\
1\end{array}$ & 64 \\
\hline $\begin{array}{l}\text { Aries } \\
\text { Abiyoga, } \\
\text { dkk }\end{array}$ & 2019 & Indonesia & 12 & 9,6 & 101 & 80 & NM & NM & 12 & 9,6 & 125 \\
\hline $\begin{array}{l}\text { Rahayu\& } \\
\text { Kamsatun }\end{array}$ & 2018 & Indonesia & NM & NM & NM & NM & NM & NM & NM & NM & NM \\
\hline \multicolumn{3}{|c|}{$\begin{array}{l}\text { Total masing- } \\
\text { masingberdasarkanumur }\end{array}$} & 25 & $\begin{array}{c}5,6 \\
3\end{array}$ & 205 & $\begin{array}{l}46, \\
17\end{array}$ & 143 & $\begin{array}{l}32, \\
20\end{array}$ & 71 & $\begin{array}{c}15,9 \\
9\end{array}$ & - \\
\hline \multicolumn{3}{|c|}{ Total responden $(n=)$} & & & & & & & & & 444 \\
\hline
\end{tabular}




\section{Prosiding Seminar Nasional Kesehatan Lembaga Penelitian dan Pengabdian Masyarakat Universitas Muhammadiyah Pekajangan Pekalongan}

2021

Berdasarkan tabel 1 diketahui bahwa hasil literature review karakteristik usia dari keenam artikel ada satu artikel yang tidak menyebutkan rentang usia responden yaitu pada artikel Rahayu \& Kamsatun (2018). Tabel 1 menunjukan bahwa responden paling banyak dalam rentang usia 20-35 tahun sebanyak $205(46,17)$ responden dan paling sedikit dalam rentang usia $<20$ tahun sebanyak $25(5,63)$ responden.

Tabel 2. Karakteristik Responden Berdasarkan Pendidikan

\begin{tabular}{|c|c|c|c|c|c|c|c|c|c|c|c|c|}
\hline \multicolumn{2}{|c|}{ Artikel } & \multicolumn{10}{|c|}{ Tingkat Pendidikan } & \multirow{3}{*}{$\begin{array}{c}\text { Jumlh } \\
\text { respo } \\
\text { nden }\end{array}$} \\
\hline \multirow[t]{2}{*}{ Penulis } & \multirow[t]{2}{*}{ Thn } & \multicolumn{2}{|c|}{$\begin{array}{c}\text { Tidak } \\
\text { Sekolah }\end{array}$} & \multicolumn{2}{|c|}{ SD } & \multicolumn{2}{|c|}{ SMP } & \multicolumn{2}{|c|}{ SMA } & \multicolumn{2}{|c|}{ PT } & \\
\hline & & $\mathbf{F}$ & $\%$ & $\mathbf{F}$ & $\%$ & $\mathbf{F}$ & $\%$ & $\mathbf{F}$ & $\%$ & $\mathbf{F}$ & $\%$ & \\
\hline $\begin{array}{l}\text { Indriyani } \\
\text { Bakri, dkk }\end{array}$ & 2019 & NM & NM & 8 & $\begin{array}{c}9,6 \\
3\end{array}$ & 14 & $\begin{array}{l}16 \\
86\end{array}$ & 51 & $\begin{array}{l}61 \\
44 \\
\end{array}$ & 10 & $\begin{array}{l}12, \\
04\end{array}$ & 83 \\
\hline $\begin{array}{l}\text { NoviraKusu } \\
\text { mayanti, } \\
\text { dkk }\end{array}$ & 2020 & NM & NM & 12 & $\begin{array}{c}18 \\
18\end{array}$ & 32 & $\begin{array}{l}48 \\
48\end{array}$ & 18 & $\begin{array}{l}27 \\
27\end{array}$ & 4 & $\begin{array}{c}6,0 \\
6\end{array}$ & 66 \\
\hline $\begin{array}{l}\text { FirianiNasut } \\
\text { ion }\end{array}$ & 2019 & 1 & $\begin{array}{c}0,9 \\
4 \\
\end{array}$ & 7 & $\begin{array}{c}6,6 \\
7\end{array}$ & 37 & $\begin{array}{l}34, \\
90\end{array}$ & 49 & $\begin{array}{l}46, \\
22 \\
\end{array}$ & 12 & $\begin{array}{l}11 \\
32 \\
\end{array}$ & 106 \\
\hline $\begin{array}{l}\text { RolitaEfrian } \\
\text { i\&Dhesi Ari } \\
\text { A }\end{array}$ & 2020 & NM & NM & 6 & $\begin{array}{c}9,3 \\
7\end{array}$ & 7 & $\begin{array}{c}10 \\
9\end{array}$ & 34 & $\begin{array}{c}53 \\
12\end{array}$ & 17 & $\begin{array}{l}26, \\
56\end{array}$ & 64 \\
\hline $\begin{array}{l}\text { Aries } \\
\text { Abiyoga, } \\
\text { dkk }\end{array}$ & 2019 & NM & NM & NM & NM & NM & NM & NM & NM & NM & NM & NM \\
\hline $\begin{array}{l}\text { Rahayu\&Ka } \\
\text { msatun }\end{array}$ & 2018 & NM & NM & NM & NM & NM & NM & NM & NM & NM & NM & NM \\
\hline $\begin{array}{l}\text { Total } \\
\text { respondenbe } \\
\text { kan Pendidik }\end{array}$ & dasar & 1 & $\begin{array}{c}0,3 \\
1\end{array}$ & 33 & $\begin{array}{l}10 \\
34\end{array}$ & 90 & $\begin{array}{l}28, \\
21\end{array}$ & 152 & $\begin{array}{l}47, \\
64\end{array}$ & 43 & $\begin{array}{l}13 \\
47\end{array}$ & - \\
\hline \multicolumn{2}{|c|}{ Jumlah total respc } & 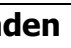 & & & & & & & & & & 319 \\
\hline
\end{tabular}

Berdasarkan tabel 2 dapat diketahui bahwa hasil literature review karakteristik tingkat pendidikan pada 6 artikel ada dua artikel yang tidak mencantumkan karakteristik tingkat pendidikan yaitu artikel Aries (2019) dan Rahayu (2018). Tabel 2 menunjukan tingkat pendidikan responden paling banyak berpendidikan SMA yaitu 152 responden (47,64\%), dan paling sedikit Tidak Sekolah yaitu 1 responden (0,31\%).

Tabel 3. Karakteristik Responden Berdasarkan Pekerjaan

\begin{tabular}{|c|c|c|c|c|c|c|}
\hline \multicolumn{2}{|l|}{ Artikel } & \multicolumn{4}{|c|}{$\begin{array}{l}\text { Status Pekerjaan } \\
\end{array}$} & \multirow{3}{*}{$\begin{array}{c}\text { Jumlahresp } \\
\text { onden }\end{array}$} \\
\hline \multirow[t]{2}{*}{ Penulis } & \multirow[t]{2}{*}{ Tahun } & \multicolumn{2}{|c|}{ Bekerja } & \multicolumn{2}{|c|}{ Tidak Bekerja } & \\
\hline & & $\mathbf{F}$ & $\%$ & $\mathbf{F}$ & $\%$ & \\
\hline Indriyani Bakri, dkk & 2019 & 15 & 18,07 & 68 & 81,92 & 83 \\
\hline $\begin{array}{l}\text { NoviraKusumayanti, } \\
\text { dkk }\end{array}$ & 2017 & 7 & 10,6 & 59 & 89,39 & 66 \\
\hline FitrianiNasution & 2020 & 74 & 69,81 & 32 & 30,18 & 106 \\
\hline $\begin{array}{l}\text { RolitaEfriani\&Dhesi } \\
\text { Ari A }\end{array}$ & 2020 & 35 & 54,68 & 29 & 45,31 & 64 \\
\hline Aries Abiyoga, dkk & 2019 & 15 & 12 & 110 & 88 & 125 \\
\hline $\begin{array}{l}\text { Rahayu\&Kamasatu } \\
\text { n }\end{array}$ & 2018 & NM & NM & NM & NM & NM \\
\hline \multicolumn{2}{|c|}{$\begin{array}{l}\text { Total respondenberdasarkan } \\
\text { status pekerjaan }\end{array}$} & 146 & 32,88 & 298 & 67,11 & - \\
\hline \multicolumn{2}{|c|}{ Total responden $(n=)$} & & & & & 444 \\
\hline
\end{tabular}




\section{Prosiding Seminar Nasional Kesehatan Lembaga Penelitian dan Pengabdian Masyarakat Universitas Muhammadiyah Pekajangan Pekalongan}

Berdasarkan table 3 dapat diketahui bahwa hasil literature review karakteristik status pekerjaan dari keenam artikel ada satu artikel yaitu rahayu \& kamsatun (2018) tidak menyebutkan karakteristik responden berdasarkan status pekerjaan, dan dari hasil kelima artikel didapat karakteristik pekerjaan ibu menyusui sebagian besar tidak bekerja yaitu 298 responden $(67,11 \%)$, dan sebagian kecil ibu menyusui bekerja yaitu 146 responden $(32,88 \%)$.

Tabel 4. Karakteristik responden berdasarkan paritas

\begin{tabular}{|c|c|c|c|c|c|c|}
\hline \multicolumn{2}{|l|}{ Artikel } & \multicolumn{4}{|c|}{ Paritas } & \multirow{3}{*}{$\begin{array}{l}\text { Jumlahr } \\
\text { espond } \\
\text { en }\end{array}$} \\
\hline \multirow[t]{2}{*}{ Penulis } & \multirow[t]{2}{*}{ Tahun } & \multicolumn{2}{|c|}{ Primipara } & \multicolumn{2}{|c|}{ Multipara } & \\
\hline & & $\mathbf{F}$ & $\%$ & $\mathbf{F}$ & $\%$ & \\
\hline Indriyani Bakri, dkk & 2019 & NM & NM & NM & NM & NM \\
\hline NoviraKusumayanti, dkk & 2017 & 19 & 28,78 & 47 & 71,21 & 66 \\
\hline FitrianiNasution & 2020 & NM & NM & NM & NM & NM \\
\hline RolitaEfriani\&Dhesi Ari A & 2020 & 22 & 34,37 & 42 & 65,62 & 64 \\
\hline Aries Abiyoga, dkk & 2019 & NM & NM & NM & NM & NM \\
\hline Rahayu\&Kamasatun & 2018 & NM & NM & NM & NM & NM \\
\hline \multicolumn{2}{|c|}{ Total respondenberdasarkanparitas } & 41 & 31,53 & 89 & 68,45 & - \\
\hline \multicolumn{2}{|c|}{ Total responden $(\mathrm{n}=)$} & & & & & 130 \\
\hline
\end{tabular}

Berdasarkan table 4 dapat diketahui bahwa dari hasil literature review karakteristik paritas dari 6 artikel hanya ada dua artikel yang menyebutkan karakteristik paritas yaitu artikel Novira, dkk (2019) dan Rolita \& Dhesi (2020) dengan hasil hamper separuh responden adalah multipara yaitu 89 responden $(68,45 \%)$, dan sebagian kecil adalah primipara 41 responden (31,53\%).

Tabel 5. Hasil Analisa Dukungan Suami

\begin{tabular}{|c|c|c|c|c|c|}
\hline \multicolumn{3}{|c|}{ Artikel } & \multirow[b]{2}{*}{$\mathbf{F}$} & \multirow[b]{2}{*}{$\%$} & \multirow[b]{2}{*}{$\begin{array}{c}\text { Jumlah } \\
\text { responden }\end{array}$} \\
\hline Penulis & Tahun & Dukungan suami & & & \\
\hline \multirow{2}{*}{$\begin{array}{l}\text { Indriyani Bakri, } \\
\text { Merry Maeta Sari, } \\
\text { \&FentiDewi Pertiwi }\end{array}$} & 2019 & Dukunganbaik & 49 & 41 & \multirow[b]{2}{*}{83} \\
\hline & & $\begin{array}{l}\text { Dukungansedang } \\
\text { Dukungankurang }\end{array}$ & $\begin{array}{c}0 \\
34\end{array}$ & $\begin{array}{c}0 \\
59\end{array}$ & \\
\hline \multirow[t]{3}{*}{ Rahayu\&Kamsatun } & 2018 & Dukunganbaik & 11 & 34,3 & \multirow{3}{*}{32} \\
\hline & & Dukungansedang & 18 & 56,2 & \\
\hline & & Dukungankurang & 3 & 9,3 & \\
\hline \multirow[t]{3}{*}{ FitrianiNasution } & 2020 & Dukunganbaik & 51 & 48,2 & \multirow[t]{3}{*}{106} \\
\hline & & Dukungansedang & 0 & 0 & \\
\hline & & Dukungankurang & 55 & 51,8 & \\
\hline \multirow{3}{*}{$\begin{array}{l}\text { RolitaEfriani, Dhesi } \\
\text { Ari Astuti }\end{array}$} & 2020 & Dukunganbaik & 20 & 31,2 & \multirow[t]{3}{*}{64} \\
\hline & & Dukungansedang & 19 & 29,6 & \\
\hline & & Dukungankurang & 25 & 39 & \\
\hline \multirow{2}{*}{$\begin{array}{l}\text { Aries Abiyoga, } \\
\text { Imam Sukirman, } \\
\text { Vera Melida }\end{array}$} & 2019 & Mendukung & 112 & 89,6 & \multirow[t]{2}{*}{125} \\
\hline & & Tidakmendukung & 13 & 10,4 & \\
\hline NoviraKusumayanti, & 2017 & Mendukung & 48 & 72,8 & \multirow[b]{2}{*}{66} \\
\hline $\begin{array}{ll}\text { Triska } & \text { Susila } \\
\text { Nindya } & \end{array}$ & & Tidakmendukung & 18 & 27,2 & \\
\hline \multicolumn{5}{|c|}{ Jumlah total responden $(n=)$} & 476 \\
\hline
\end{tabular}

Berdasarkan tabel 5 dapat diketahui bahwa hasil literature review pada enam artikel ada empat artikel yaitu artikel Indriyani (2019), Fitriani (2020), Rolita (2020) dan Rahayu (2018) menyebutkan paling banyak responden mendapat dukungan baik yaitu 131 responden, dan paling sedikit yaitu 37 responden mendapat dukungan 


\section{Prosiding Seminar Nasional Kesehatan Lembaga Penelitian dan Pengabdian Masyarakat Universitas Muhammadiyah Pekajangan Pekalongan}

sedang. Sedangkan pada dua artikel yaitu artikel Novira (2017) dan Aries (2019) menyebutkan paling banyak responden mendapatkan dukungan suami yaitu 160 responden, dan paling sedikit 31 responden tidak mendapat dukungan dari suami. Jadi kesimpulannya adalah responden lebih banyak yang mendapatkan dukungan.

Tabel 6. Hasil Analisa Pemberian ASI Eksklusif

\begin{tabular}{|c|c|c|c|c|c|c|}
\hline \multicolumn{2}{|l|}{ Artikel } & \multicolumn{4}{|c|}{ Pemberian ASI Eksklusif } & \multirow{3}{*}{$\begin{array}{c}\text { Jumlah } \\
\text { responden }\end{array}$} \\
\hline \multirow[t]{2}{*}{ Penulis } & \multirow[t]{2}{*}{ Tahun } & \multicolumn{2}{|c|}{ ASI Eksklusif } & \multicolumn{2}{|c|}{ Tidak ASI Eksklusif } & \\
\hline & & $\mathbf{F}$ & $\%$ & $\mathbf{F}$ & $\%$ & \\
\hline Indriyani Bakri, dkk & 2019 & 54 & 65,0 & 29 & 34,9 & 83 \\
\hline NoviraKusumayanti, dkk & 2017 & 14 & 21,21 & 52 & 78,78 & 66 \\
\hline FitrianiNasution & 2020 & 9 & 8,49 & 97 & 91,50 & 106 \\
\hline $\begin{array}{l}\text { RolitaEfriani\&Dhesi } \\
\text { Ari A }\end{array}$ & 2020 & 26 & 40,62 & 38 & 59,37 & 64 \\
\hline Aries Abiyoga, dkk & 2019 & 117 & 93,6 & 8 & 6,4 & 125 \\
\hline Rahayu\&Kamasatun & 2018 & 26 & 81,25 & 6 & 18,75 & 32 \\
\hline $\begin{array}{l}\text { Total } \\
\text { respondenberdasarkanp } \\
\text { n ASI eksklusif }\end{array}$ & emberia & 246 & 51,68 & 230 & 48,31 & - \\
\hline \multicolumn{2}{|c|}{ Total responden $(\mathrm{n}=)$} & & & & & 476 \\
\hline
\end{tabular}

Berdasarkan tabel 6 dapat diketahui bahwa lietarture review dari 6 artikel menunjukan hasil hamper separuh yaitu 246 responden $(51,68 \%)$ memberikan ASI Eksklusif, dan sebagian kecil yaitu 230 responden (48,31\%) tidak memberikan ASI secara Eksklusif.

Tabel 7. Hasil Analisa hubungandukungansuamidengan pemberian ASI Eksklusif

\begin{tabular}{|c|c|c|c|}
\hline \multicolumn{2}{|l|}{ Artikel } & \multirow{2}{*}{$\begin{array}{c}P \\
\text { value }\end{array}$} & \multirow[t]{2}{*}{ Keterangan } \\
\hline Penulis & Tahun & & \\
\hline FitrianiNasution & 2020 & 0.014 & $\begin{array}{c}\text { Ada } \\
\text { Hubungandukungansuamidenganpemberian } \\
\text { ASI Eksklusif }\end{array}$ \\
\hline $\begin{array}{l}\text { RolitaEfriani\&Dhesi Ari } \\
\text { A }\end{array}$ & 2020 & 0.019 & $\begin{array}{c}\text { Ada } \\
\text { Hubungandukungansuamidenganpemberian } \\
\text { ASI Eksklusif }\end{array}$ \\
\hline Aries Abiyoga, dkk & 2019 & 0.037 & $\begin{array}{c}\text { Ada } \\
\text { Hubungandukungansuamidenganpemberian } \\
\text { ASI Eksklusif }\end{array}$ \\
\hline Indriyani Bakri, dkk & 2019 & 0.220 & $\begin{array}{c}\text { Tidak Ada } \\
\text { Hubungandukungansuamidenganpemberian } \\
\text { ASI Eksklusif }\end{array}$ \\
\hline NoviraKusumayanti,dkk & 2017 & 0.058 & $\begin{array}{c}\text { Tidak Ada } \\
\text { Hubungandukungansuamidenganpemberian } \\
\text { ASI Eksklusif }\end{array}$ \\
\hline Rahayu\&Kamsatun & 2018 & 0.530 & $\begin{array}{c}\text { Tidak Ada } \\
\text { Hubungandukungansuamidenganpemberian } \\
\text { ASI Eksklusif }\end{array}$ \\
\hline
\end{tabular}

Berdasarkan hasil analisis literature review pada tabel 7 Dapat diketahui bahwa dari keenam artikel dengan hasil uji signifikan 0.05 menunjukan 3 artikel yaitu pada artikel penelitian dari Fitriani (2020), Rolita (2020), dan Aries (2019) memiliki nilai $p$ value $<0.05$ yang berarti ada hubungan antara dukungan suami dengan pemberian ASI Eksklusif, dan 3 artikel lain yaitu artikel penelitian dari Indriyani (2019), Novira 


\section{Prosiding Seminar Nasional Kesehatan $\mathbf{2 0 2 1}$ Lembaga Penelitian dan Pengabdian Masyarakat Universitas Muhammadiyah Pekajangan Pekalongan}

(2017), dan Rahayu (2018) memiliki nilai $p$ value $>0.05$ yang berarti tidak ada hubungan antara dukungan suami dengan pemberian ASI Eksklusif.

\section{Pembahasan \\ Usia}

Berdasarkan literature review terhadap 6 jurnal mengenai data karakteristik terdapat satu artikel yang tidak mencantumkan karakteristik responden yaitu artikel Rahayu \& Kamsatun (2018). Menurut data karakteristik umur responden ibu menyusui terbanyak pada usia 20-35 tahun yaitu 205 (46,17\%) responden. Hal ini sejalan dengan hasil penelitian Febriyanti dan Putu [12] dengan hasil responden paling banyak pada usia 20-35 tahun yaitu 25 responden (62,5\%). Sitopu [13] menjelaskan bahwa pada kategori usia ini adalah yang tepat dalam proses kehamilan, persalinan, dan nifas dengan harapan bahwa ibu benar-benar siap dalam menghadapi proses kehamilan, melahirkan dan menyusui, sudah benar-benar matang secara fisik dan psikologis.

Dalam kurun waktu reproduksi sehat dikenal usia aman untuk kehamilan, persalinan, dan menyusui adalah 20-35 tahun. Oleh sebab itu, usia tersebut sesuai dengan masa reproduksi sehingga sangat baik dan sangat mendukung dalam pemberian ASI Ekslusif, sedangkan umur yang kurang dari 20 tahun dianggap masih belum matang secara fisik, mental, dan psikologis dalam mengahadapi kehamilan, persalinan, serta pemberian ASI. Sedangkan umur lebih dari 35 tahun dianggap berbahaya, sebab baik alat reproduksi maupun fisik ibu sudah jauh berkurang dan menurun, selain itu bias terjadi resiko bawaan pada bayi dan juga dapat meningkatkan kesulitan pada kehamilan persalinan dan menyusui [14].

\section{Tingkat Pendidikan}

Berdasarkan karakteristik pendidikan responden terbanyak berada pada tingkat pendidikan SMA sebanyak 152 (47,64\%) responden. Pada hasil penelitian Astuti [10] menyatakan bahwa adanya hubungan yang signifikan antara pendidikan dengan pemberian ASI Eksklusif. Pendidikan merupakan salah satu faktor yang mempengaruhi pemberian ASI Eksklusif. Semakin tinggi pendidikan seseorang, semakin menerima informasi sehingga semakin banyak pengetahuan yang dimiliki, sebaliknya pendidikan yang kurang akan menghambat perkembangan sikap seseorang terhadap nilai-nilai baru. Dari pernyataan tersebut maka ib umenyusui dengan latar belakang pendidikan yang tinggi akan lebih mudah memperoleh dan mengingat informasi yang diberikan tentang inisiasi menyusu dini dan pola pemberian ASI Eksklusif [15].

\section{Status Pekerjaan}

Berdasarkan karakteristik pekerjaan responden mayoritas tidak bekerja sebanyak $298(67,11 \%)$ responden, dan sebagian kecil 146 (32,88\%) responden bekerja. Pada penelitian Sitopu [13] menyebutkan bahwa ibu yang bekerja mempunyai waktu yang terbatas untuk keluarga. Waktunya terbagi dengan urusan pekerjaan diluar rumah, sehingga menyebabkan tidak dapat sehari penuh terlibat dalam pemberian ASI sehingga intensitas bayi menyusu akan berkurang, proses pengeluaran ASI sangat didukung dengan intensitas pertemuan antara ibu dan bayi. 


\section{Prosiding Seminar Nasional Kesehatan Lembaga Penelitian dan Pengabdian Masyarakat Universitas Muhammadiyah Pekajangan Pekalongan}

Karena bekerja ibu tidak dapat berhubungan penuh dengan bayinya, akibatnya ibu cenderung memberikan susu formula yang diberikan melalui botol, menyebabkan frekuensi penyusuan akan berkurang dan produksi ASI akan menurun. Keadaan ini menyebabkan ibu menghentikan pemberian ASI. Jadi seorang ibu yang bekerja kemungkinan menyusui bayinya secara eksklusif menurun drastis[14].

\section{Paritas}

Berdasarkan karakteristik paritas responden sebagaian sebagian besar yaitu 89 responden $(68,45 \%)$ berasal dari paritas multipara dan sebagian kecil responden yaitu 41 responden $(31,53 \%)$ berasal dari paritas primipara. Hal ini sejalan dengan penelitian Febriyanti dan Putu [12] yang menyatakan bahwa dari 40 responden sebagian besar responden yaitu 34 responden $(85,0 \%)$ berasal dari paritas multipara dab sebagian kecil yaitu 6 responden $(15,0 \%)$ berasal dari paritas primipara.Paritas dikaitkan dengan pengalaman ibu saat menyusui. Hal ini berkaitan dengan jumlah anak yang pernah disusui ibunya. Perlu ada jarak antara kelahiran anak yang satu dengan kehamilan berikutnya setidaknya 18 bulan sampai 2 tahun agar ibu memiliki kesempatan untuk menyusui. Keadaan fisik ibu akan terlalu berat jika harus menyusui dan hamil lagi. Disamping itu kehamilan juga akan mengurangi jumlah ASI yang dikeluarkan bahkan mungkin berhenti sama sekali [16].

\section{DukunganSuami}

Berdasarkan hasil univariat dukungan suami sebagian besar responden mendapat dukungan dari suami yaitu, dibandingkan dengan yang tidak mendapat dukungan dari suami yaitu 31 responden. Hal ini sesuai dengan penelitian Fahrudin etal. [17] dengan hasil sebanyak 53 responden $(75,71 \%)$ mendapat dukungan dan 17 responden $(24,28 \%)$ tidak mendapat dukungan dari suaminya.

Dukungan adalah suatu upaya yang diberikan kepada orang lain, baik moril maupun materiil untuk memotivasi orang tersebut dalam melaksanakan kegiatan, dalam hal ini adalah dukungan suami [16]. Dukungan suami sangat menentukan keberhasilan menyusui. Karena pengaruh keluarga terutama suami berdampak pada kondisi emosi ibu sehingga secara tidak langsung mempengaruhi produksi ASI [8].

\section{Pemberian ASI Eksklusif}

Berdasarkan hasil univariat pemberian ASI Eksklusif, hamper separuh responden memberikan ASI secara Eksklusif yaitu sebanyak 246 (51,68\%) responden dan sebanyak 230 (48,31\%) responden tidak memberikan ASI secara Eksklusif. Hal ini sejalan dengan penelitian yang dilakukan oleh Gusrinawatidan Hardisman [18] dengan hasil responden yang memberikan ASI secara Eksklusif lebih banyak yaitu 205 responden $(73,5 \%)$ dibandingkan dengan yang tidak memberikan ASI secara Eksklusif sebanyak 74 responden (26,5\%). Pemberian ASI secara eksklusif dianjurkan untuk jangka waktu setidaknya selama 6 bulan. Setelah bayi berumur 6 bulan, ia harus mulai diperkenalkan dengan makanan padat, sedangkan ASI dapat diberikan sampai bayi berusia 2 tahun atau lebih. Para ahli menemukan bahwa manfaat ASI akan sangat meningkat bila bayi hanya diberi ASI saja selama 6 bulan pertama kehidupannya. Peningkatan ini sesuai dengan lamanya pemberian ASI Eksklusif serta lamanya 


\section{Prosiding Seminar Nasional Kesehatan Lembaga Penelitian dan Pengabdian Masyarakat Universitas Muhammadiyah Pekajangan Pekalongan}

pemberian ASI bersama-sama dengan makanan padat setelah bayi berusia 6 bulan $[16]$.

\section{Hubungan Dukungan Suami dengan Pemberian ASI Eeksklusif}

Berdasarkan literature review terhadap 6 artikel mengenai hubungan dukungan suami dengan pemberian ASI Eksklusif menunjukanhasil 3 artikel terdapat hubungan dukungan suami dengan pemberian ASI Eksklusif dan 3 artikel tidak terdapat hubungan dukungan suami dengan pemberian ASI Eksklusif. Penelitian Bangkele et al. [19] didapatkan $p$ value 0,000 yang berarti ada hubungan antara dukungan suami dengan pemberian ASI Eksklusif. Untuk hubungan dukungan suami terhadap pemberian ASI Ekslusif memberikan hubungan positif yang dilihat berdasarkan nilai phi pada uji chi square yang menunjukan hasil 0,754 artinya hubungan yang bersifat satu arah.

Penelitian Ratna ningshing [20] diperoleh $p$ value 0,03 yang berarti value lebih kecil dari taraf signifikan $5 \%(0,03<0,05)$ sehingga hasil yang didapat $\mathrm{H}$ diterima yang artinya terdapat hubungan antara dukungan suami dengan pemberian ASI Eksklusif. Ibu yang mendapat dukungan dari suami lebih besar peluangnya untuk memberikan ASI secara Eksklusif dibandingkan dengan ibu yang tidak mendapatkan dukungan dari suaminya.

Adanya hubungan yang bermakna antara dukungan suami dengan pemberian ASI ditunjukan dengan seorang suami yang berperan sebagai breastfeeding father, yang akan membantu ibu mengurus bayinya, seperti menggendong bayi, memandikan, mengganti popok, serta mengajaknya bermain. Sementara itu, ibu dapat beristirahat cukup agar produksi ASI lebih banyak [9]. Dukungan suami mempunyai peran besar dalam keberhasilan memberikan ASI Eksklusif. Semakin besar dukungan suami maka semakin besar juga peluang ibu untuk menyusui bayinya. Hal ini akan mempengaruhi kelancaran refleks pengeluaran ASI, karena refleks tersebut dipengaruhi oleh perasaan dan emosi ibu. Dukungan suami diperlukan untuk menghasilkan ketenangan, ketentraman, dan kenyamanan ibu menyusui yang dapat meningkatkan produksi hormone oksitosin, sehingga dapat meningkatkan pemberian ASI [20].Pemberian ASI Eksklusif lebih meningkat bila mendapat dukungan, kasih sayang, bantuan dan persahabatan dari suami [21].

Penelitian Oktalina et al. [22] menunjukan tidak ada hubungan antara dukungan suami dengan pemberian ASI Eksklusif dengan nilai $p$ value 0,090 . Hal ini sejalan dengan penelitian yang dilakukan oleh Yanti et al. [23] yang juga menunjukan tidak hubungan antara dukungan suami dengan pemberian ASI Eksklusif.Fahrudin et al. [17] menjelaskan bahwa banyak faktor yang dapat mempengaruhi pemberian ASI Eksklusif antara lain umur, pendidikan, dan status pekerjaan. Termasuk didalamnya adalah dukungan sosial dari terutama dari keluarga terdekat yaitu suami. Keberhasilan menyusui sangat ditentukan oleh peran ayah karena ayah akan turut menentukan kelancaran refleks pengeluaran ASI yang sangat dipengaruhi oleh keadaan emosi atau perasaan ibu.

Yuliana et al. [24] menjelaskan hubungan tidak bermakna antara dukungan suami dengan pemberian ASI Eksklusif dimungkinkan jika suami tidak memiliki pengetahuan yang cukup mengenai ASI Eksklusif. Faktor lain yang memungkinkan tidak ada 


\section{Prosiding Seminar Nasional Kesehatan Lembaga Penelitian dan Pengabdian Masyarakat Universitas Muhammadiyah Pekajangan Pekalongan}

hubungan antara dukungan suami dengan pemberian ASI Eksklusif yaitu masih banyak suami yang berpendapat bahwa menyusui adalah urusan ibu dan bayinya. Selain itu faktor pekerjaan dan kelelahan bekerja juga sangat mempengaruhi dukungan suami yang diberikan.

\section{Simpulan dan Saran}

Dari telaah yang dilakukan terhadap 6 artikel dapat disimpulkan bahwa berdasarkan karakteristik usia sebagian besar responden berusia 20-35 tahun, pendidikan responden hampir separuh berpendidikan SMA yaitu 152 responden $(47,64 \%)$, status pekerjaan sebagian besar responden tidak bekerja sebanyak 298 responden $(67,11 \%)$ dan status paritas responden sebagian besar multipara sebanyak 89 responden $(68,45 \%)$. Berdasarkan dukungan suami, sebagian besar responden mendapatkan dukungan dari suami. Berdasarkan pemberian ASI eksklusif separuh responden $246(51,68 \%)$ memberikan ASI secara eksklusif. Berdasarkan hubungan dukungan suami dengan pemberian ASIE eksklusif, terdapat tiga artikel yang menyatakan ada hubungan antara dukungan suami dengan pemberian ASI Eksklusif dengan $p$ value $(0,014-0,037)$ dan tiga artikel lagi menyebutkan tidak ada hubungan antara dukungan suami dengan pemberian ASI Eksklusif dengan $p$ value $(0,058-$ $0,530)$.

Dukungan suami dapat mempengaruhi pemberian ASI Eksklusif sehingga dalam penerapan asuhan keperawatan seharusnya melibatkan suami serta mempertegas bahwa peran serta suami dalam pemberian ASI sangatlah penting. Perlunya edukasi terkait pemberian ASI pada suami, agar para suami dapat mengerti tentang dukungan suami pada pemberian ASI Eksklusif, edukasi tersebut dapat dijadikan intervensi dalam pemberian asuhan keperawatan.

\section{Referensi}

[1] F. Fartaeni, F. D. Pertiwi, and I. Avianty, "Hubungan Pengetahuan, Sikap, Dan Dukungan Suami Terhadap Pemberian ASI Eksklusif Di Desa Pabuaran Kecamatan Gunung Sindur," HEARTY Jurnal Kesehatan Masyarakat, vol. 6, no. 1, pp. 1-8, 2018.

http://ejournal.uika-bogor.ac.id/index.php/Hearty/article/view/1255

[2] Kementrian Kesehatan Indonesia,Data Dan Informasi Profil Kesehatan Indonesia Tahun 2019,2020. https://pusdatin.kemkes.go.id/folder/view/01/structurepublikasi-data-pusat-dan-informasi.html

[3] Mufdlilah, Kebijakan Pemberian ASI Eksklusif : Kendala \& Komunikasi, Yogyakarta : NuhaMedika, 2019.

[4] Kementrian Kesehatan Indonesia, Berikan ASI untuk Tumbuh Kembang Optimal, 2019.

https://sehatnegriku.kemkes.go.id/baca/rilismedia/20190807/1331200/berikanasi-tumbuh-kembang-optimal/

[5] Kementrian Kesehatan Indonesia, Pedoman Penyelenggaraan Pekan ASI Sedunia (PAS) Tahun 2017, 2017. 


\section{Prosiding Seminar Nasional Kesehatan Lembaga Penelitian dan Pengabdian Masyarakat Universitas Muhammadiyah Pekajangan Pekalongan}

https://sehatnegriku.kemkes.go.id/baca/rilismedia/20170809/0122144/menyusuidapat-menurunkan-angka-kematian-bayi/

[6] Dinas Kesehatan Provinsi Jawa Tengah, Profil Kesehatan ProvinsiJawa Tengah Tahun 2019, Badan Pusat Statistik Provinsi Jawa Tengah, 2020.

https://dinkesjatengprov.go.id/v2018/storegge/2020/09/Profil-Jateng-Tahun2019.pdf.

[7] UNICEF, Breastfeeding, 2019.https://data.unicef.org/topic/nutrion/infant-andyoung-child-feeding/

[8] R. Haryono, and S. Setianingsih, Manfaat ASI Eksklusifuntuk Buah Hati Anda, Yogyakarta : Gosyen Publisihing, 2014.

[9] N. Khasanah, ASI atau Susu Formula ya?, Yogyakarta : Flashbooks, 2011.

[10] I. Astuti, "Determinan Pemberian ASI Eksklusif pada Ibu Menyusui," Jurnal Health Quality, vol. 4, no. 1, pp. 1-76, 2013. https://www.poltekkesjakarta1.ac.id/wpcontent/uploads/legacy/jurnal/dokumen/ 41Jurnal ISRONI.pdf

[11] S.A. Yuliana, Y. Ernawati, and Febrian H, "Hubungan Dukungan Social Suami Dengan Keberhasilan Pemberian ASI Eksklusif di Desa Mandurejo Prambanan," MIKKI, vol. 8, no. 2, pp. 61-68, 2019.

http://webcache.googleusercontent.com/search?q=cache:xqFHPtJYsEsJ:jurnaln asional.ump.ac.id/index.php/HMJ/article/view/7671+\&cd=1\&hl=id\&ct=clnk\&gl=id

[12] N. M. Febriyanti, and Ni Putu W.L.D, "Faktor-faktor Yang Mempengaruhi Pemberian ASI Eksklusif Di Banjar Kaja Sesetan Wilayah KerjaPuskesmas I Denpasar Selatan," Jurnal MID-Z, vol. 2, no. 2, pp. 48-51, 2019.

http://ejurnal.uij.ac.id/index.php/JM/article/view/508

[13] S. D. Sitopu, "Hubungan Dukungan Suami Dengan Pemberian ASI Di Kelurahan Lalang Wilayah Kerja Puskesmas Desa Lalang Kecamatan Medan Sunggal," AnNadaa, pp. 1-5, 2017.2 https://ojs.uniskabjm.ac.id/index.php/ANN/article/view/977

[14] Nurhayati, I. Holidy, and Al. M, "Faktor-faktor Yang Berhubungan Dengan Pemberian ASI Ekslusif di Desa Candimas," Jurnal Keperawatan, vol. 9, no. 1, pp. 86-95, 2015.

http://www.ejurnal.poltekkes-tjk.ac.id/index.php/JKEP/article/view/524

[15] E. Wahyutri, S. Nuralis, K. Umi, and Edi, P, Menurunkan Resiko Prevalensi Diare dan Meningkatkan Ekonomi Melalui ASI Eksklusif, Scopindo Media Pustaka : Surabaya, 2020.

[16] P. Simbolon, Dukungan Keluarga dalam Pemberian ASI Eksklusif, Yogyakarta :Deepublish, 2017. 


\section{Prosiding Seminar Nasional Kesehatan \\ Lembaga Penelitian dan Pengabdian Masyarakat Universitas Muhammadiyah Pekajangan Pekalongan}

[17] I. Fahrudin, U.S. Devi, I. Burhanuddin, and A. Tri, "Hubungan status pekerjaan ibu dan dukungan suami terhadap pemberian ASI Eksklusif," Herb-medicine journal, vol. 3, no. 3, pp. 91-99, 2020.

http://jurnalnasional.ump.ac.id/index.php/HMJ/article/view/7671

[18] Gusrinawati \& Hardisman, "Hubungan Pendidikan, Sikap, Dan Dukungan Suami Dengan Keberhasilan Pemberian ASI Eksklusif Di Kota Bukit Tinggi," Jurnal $\begin{array}{lllll}\text { Bonanza, vol. } 1 \text {, no. 2, pp. } 2020.79, & \end{array}$ http://ojs.stiehas.ac.id/index.php/MB/article/view/294

[19] E.Y.Bangkele, L. A. Febiana A.D, and W.M.Soemarji, "Hubungan Pengetahuan, Sikap, Dan Dukungan Suami Terhadap Pemberian ASI Eksklusif Di Kelurahan Pengawu Wilayah Kerja Puskesmas Nasorara, "Jurnal Kesehatan Tadulako, vol.4, no. 2, pp. 1-63, 2018.

https://jurnal.fk.untad.ac.id/index.php/htj/article/download/67/66

[20] E. Ratnaningsih,"Dukungan Suami Kepada Istri Dalam Upaya Pemberian ASI Di Rumah Sakit Panti Wilasa Citarum Semarang," Jurnal Ilmiah Ilmu Kebidanan Dan Kesehatan Sekolah Tinggi Ilmu Kesehatan Bakti Utama Pati, vol. 11, no. 1, pp. 09-19, 2020. https://www.jurnal.stikesbup.ac.id/index.php/jks/article/view/59

[21] F. Lutfiana, and M. Rifatul,"Hubungan Dukungan Suami dan Sikap Ibu Menyusui dengan Praktik Pemberian ASI Eksklusif," Jurnal Ilmiah Gizi Dan Kesehatan (JIGK), vol. $1, \quad$ no.1, pp. 2019. http://jurnal.umus.ac.id/index.php/JIGK/article/view/98

[22] O. Oktalina, M.Lailatul, andA. Sri, "Hubungan Dukungan Suami Dan Dukungan Keluarga Dengan Pemberian ASI Eksklusif Pada Ibu Anggota Kelompok Pendukung ASI (KP-ASI), "Media Gizi Indonesia, vol.10, no.1, pp. 64-70, 2015. https://www.e-journal.unair.ac.id/MGI/article/view/3128

[23] P.D. Yanti, I. Q. Nurul, and D.Siska, "Hubungan Pengetahuan, Dukungan Suami dan Pekerjaan Dengan Pemberian ASI Eksklusif Diwilayah Kerja UPT Puskesmas Karang Intan 2 Kabupaten Banjar Tahun 2020," pp. 1-10, 2020. http://eprints.uniska-bjm.ac.id/2326/

[24] S.A. Yuliana,Y. Ernawati,and Febrian H, "Hubungan Dukungan Sosial Suami Dengan Keberhasilan Pemberian ASI Eksklusif di Desa Mandurejo Prambanan,"MIKKI,vol.8,no.2, pp. 61-68,2019.

http://webcache.googleusercontent.com/search?q=cache:xqFHPtJYsEsJ:jurnaln asional.ump.ac.id/index.php/HMJ/article/view/7671+\&cd=1\&hl=id\&ct=clnk\&gl=id 